\title{
Barium Sulfate Scale Removal at Low-Temperature
}

\author{
Hany Gamal, ${ }^{1}$ Saad Al-Afnan, ${ }^{1}$ Salaheldin Elkatatny $\mathbb{D}^{1},{ }^{1}$ and Mohamed Bahgat ${ }^{2}$ \\ ${ }^{1}$ Department of Petroleum Engineering, College of Petroleum \& Geosciences, King Fahd University of Petroleum \& Minerals, \\ Dhahran 31261, Saudi Arabia \\ ${ }^{2}$ Rosewell Energy Company, 327 El-Horreya Road, Cleopatra, Alexandria 21500, Egypt
}

Correspondence should be addressed to Salaheldin Elkatatny; elkatatny@kfupm.edu.sa

Received 1 February 2021; Revised 2 March 2021; Accepted 13 March 2021; Published 23 March 2021

Academic Editor: Guozhong $\mathrm{Hu}$

Copyright ( 92021 Hany Gamal et al. This is an open access article distributed under the Creative Commons Attribution License, which permits unrestricted use, distribution, and reproduction in any medium, provided the original work is properly cited.

\begin{abstract}
Precipitation of the scale in the oil and gas reservoirs, surface and subsurface equipment, and processing and production facilities is a big problem as it affects petroleum production. The scale precipitations decrease the oil and gas production and cause economical loss. Solving this issue requires an engineering investigation to provide a safe, efficient, and economic solution. Consequently, this study proposed a developed dissolver for barium sulfate scales, where two field-scale samples were collected from different locations. The compositional analysis for scale samples showed that sample 1 is $100 \%$ barium sulfate where sample 2 has $97.75 \%$ barium sulfate and $2.25 \%$ of quartz. The composition of the developed dissolver has diethylenetriamine pentaacetic acid (DTPA) as a chelating agent, oxalic acid, and tannic acids as an activator, nonionic surfactant, and water as the base fluid. The new dissolver was investigated with extensive lab tests to determine the dissolution efficiency, precipitation tendency for the dissolved scale solids, corrosion rate, and fluid-rock interaction. The obtained successful results indicated that the developed dissolver had a dissolution efficiency for two real barium scale samples as the results showed 76.9 and $71.2 \%$ at $35^{\circ} \mathrm{C}$ and 91.3 and $78.4 \%$ at $90^{\circ} \mathrm{C}$ for samples 1 and 2, respectively. The new solution has a great performance compared with common scale dissolvers in the oil field as hydrochloric acid, ethylenediaminetetraacetic acid, and diethylenetriamine pentaacetic acid. The developed dissolver showed a very low precipitation tendency for the scale dissolved solids ( 1.9 and $3.2 \%$ for samples 1 and 2 , respectively) under $35^{\circ} \mathrm{C}$ for 24 hours. Without any additives of corrosion inhibitors, the corrosion rate was $0.001835 \mathrm{~g} / \mathrm{cm}^{2}$ at 6.9 $\mathrm{MPa}$ and $100^{\circ} \mathrm{C}$ for 6 hours. Injecting the developed dissolver for damaged sandstone core sample with barite mud by flooding test showed a return permeability of $115 \%$.
\end{abstract}

\section{Introduction}

The oil and gas industry suffers from the scale precipitation in the well equipment. The scale depositions will affect the internal capacity for the well equipment either downhole or at the surface as the production tubing, subsurface valves, wellhead, surface pipelines, and production and processing facilities, in addition to, the reservoir formation [1-4]. The scale precipitation causes formation damage, decreases the reservoir injectivity and productivity performance, and also changes the rock wettability $[5,6]$.

There are many reasons for the scale deposits and exposing many fluid streams during the production cycle was found to be the most critical factor as these streams have different ions and concentrations. These streams might include the oil, formation water, and injected water and will format different types of scales [4]. Barium and calcium minerals are commonly found with higher concentrations in the formation water than the seawater; moreover, a higher concentration of sulfate ions is commonly existing with the seawater than the formation water [7]. Many different types of scales are prevalent with the oil and gas field from the sulfate type as barium sulfate which is commonly called barite $\left(\mathrm{BaSO}_{4}\right)$, calcium sulfate $\left(\mathrm{CaSO}_{4}\right)$, and strontium sulfate $\left(\mathrm{SrSO}_{4}\right)[8,9]$.

Many operational parameters and conditions have a great impact on the scale precipitations in the field as pressure, temperature, interaction time, degree of acidity or alkalinity $\mathrm{pH}$, and chemical equilibrium [10]. The location of the scale and its type will occur based on the streams' ions concentrations and the operating conditions. One of the hardest scale types is the sulfate scales that are commonly formatted due to the incompatibility between the two water streams of 
production and injection water, and this scale type is a hard scale for removal as it has a low dissolution rate with acid [11]. The barium sulfate (barite) is commonly used with the drilling fluids to obtain the required mud type for well control issues $[12,13]$, and the incompetent practices and poor design during the drilling operations might cause formation damage by the barite solids precipitations in the drilled rock pore system [14-16]. Many sulfate scales are precipitated in the reservoir section and the well pumps of artificial lift equipment [17].

1.1. Scale Removal Solutions. The field scales removal operations are considered critical jobs due to the composite scales from different types with changing the operation conditions along the production stream. Two common methodologies are applied in the field of descaling that includes the mechanical or the chemical solutions and, in some cases, can be applied together. The descaling process should be designed from technical and economic aspects $[18,19]$. The scale precipitations might lead to production reduction or shutdown [20], and hence, utilizing the scale inhibitors might be efficient for preventing the scale deposition [7, 21, 22]. The proper chemical design for the scale inhibitors has shown successful results for field applications [23].

Designing the chemical scale dissolver should investigate the scale solubility by chemical reactions and dissolution mechanisms to develop a highly efficient scale dissolver for the field descale operations [4]. The solution $\mathrm{pH}$ is a critical parameter that affects the scale solubility with the developed dissolver [24]. The $\mathrm{pH}$ of the developed chemical solution for scale removal will have a great impact on the equipment integrity due to the corrosive effect $[25,26]$. Recently, many studies in the literature are targeting high $\mathrm{pH}$ solutions [27-30]. The high $\mathrm{pH}$ scale dissolvers will not damage the well tubular and equipment as the corrosion rate is low. At the same time, high $\mathrm{pH}$ solutions will save the additional cost that is commonly applied for the scale inhibitors and intensifiers $[31,32]$. A study was performed to provide a scale dissolver with a $12.5 \mathrm{pH}$ value for removing sulfate and/or sulfide scale types by employing specific concentrations of ethylenediamine, nitrilotriacetic acid (NTA), and chloroacetic acid [33].

Tetrakis hydroxymethyl phosphonium salt (THPS) was studied to be added to the ethylenediaminetetraacetic acid (EDTA) to develop a chemical scale dissolver with a $\mathrm{pH}$ of 8 to enhance the alkalinity base for the solution [28]. Organic and inorganic acids are commonly utilized in the oil and gas field for scale removal purposes [34]. Commonly, a surfactant is added to the chemical solution to remove the hydrocarbon layer from the scale solids to increase the interaction between the scale body and the chemical solution to provide a higher dissolution rate. Hydrochloric acid $(\mathrm{HCl})$ is one of the most common acids for scale removal applications in the petroleum industry [35]. Among the undesirable side effects of hydrochloric acid, the corrosive impact and producing hydrogen sulfide toxic gas. Therefore, specific chemical additions need to be added to control these impacts during the scale removal jobs [5,36-38]. In addition to that, the performance of $\mathrm{HCl}$ was found efficient in specific scale types as zinc sulfides [39], pyrrhotite, and troilite of iron sulfides. However, the results did not show great solubility with sulfate scales as strontium, calcium, and barium [20, 21]. Organic acids as citric acid, maleic acid, formic acid, and acetic acid were employed for the scale removal at highpressure high-temperature reservoirs [40-42]. The organic acids have a low corrosive impact on the equipment and have along-time chemical reactions; however, the scale dissolution rate is relatively low [41].

The chelating agents were studied for scale dissolution as an alternative for the organic and inorganic acids. The chelating agents have many advantages as they have a small corrosive rate, are safely handled, and environmentally friendly [43]. Among these chelating agents ethylenediaminetetraacetic acid (EDTA), hydroxyethyl ethylene diamine triacetic acid (HEDTA), hydroxyethyl iminodiacetic acid (HIDA), diethylenetriamine pentaacetic acid (DTPA), and methylglycinediacetic acid (MGDA) showed successful applications for scale removal in the oil and gas field. However, the high cost, $\mathrm{pH}$ optimization, effective concentration, descale exposure time, and thermal stability are considered the most common disadvantages for employing the chelating agents for the scale removal operations [29, 44, 45].

The barium sulfate scale was found to decrease the reservoir rock permeability, and the temperature is a critical parameter for the barium sulfate scale deposition as the precipitation decreases at the higher temperature [7]. The chelating agents were studied for removing the barium sulfate scale; Bageri et al. [13] developed a novel solution by employing the diethylenetriamine pentaacetic acid with a special catalyst, and the study results showed an enhancement of the dissolution efficiency for the barium sulfate scale removal.

The current study proposed a developed scale dissolver for removing the barium sulfate scale precipitations. The study provides new contributions in terms of the high dissolution rates for the developed dissolver for two real field samples of barium sulfate scale type, high efficiency at lowtemperature conditions $\left(35^{\circ} \mathrm{C}\right)$ for the surface scale treatment, low corrosive rate to maintain the well equipment and field facilities integrity, high $\mathrm{pH}$ for the developed dissolver of 9.78, low precipitation tendency for the dissolved solids after the solubility process, and the developed chemical solution provided a great permeability enhancement throughout the core flooding test for a damaged core sample with barite-weighted mud. In addition, the dissolution performance for the developed dissolver was compared with the common dissolvers in the oil industry named $\mathrm{HCl}$ acid (15 wt.\%), EDTA (20 wt.\%), and DTPA (20wt.\%), and the results showed the highest performance for the developed scale dissolver over the other dissolvers under the same condition. Through the study, extensive lab analysis was performed for the field produced water, injected water, and collected field scale samples to design an efficient scale dissolver.

\section{Materials and Experimental Work}

Figure 1 shows the proposed layout for the study, starting from the field scale samples collection, followed by the routine chemical analysis for the scale samples and the water 


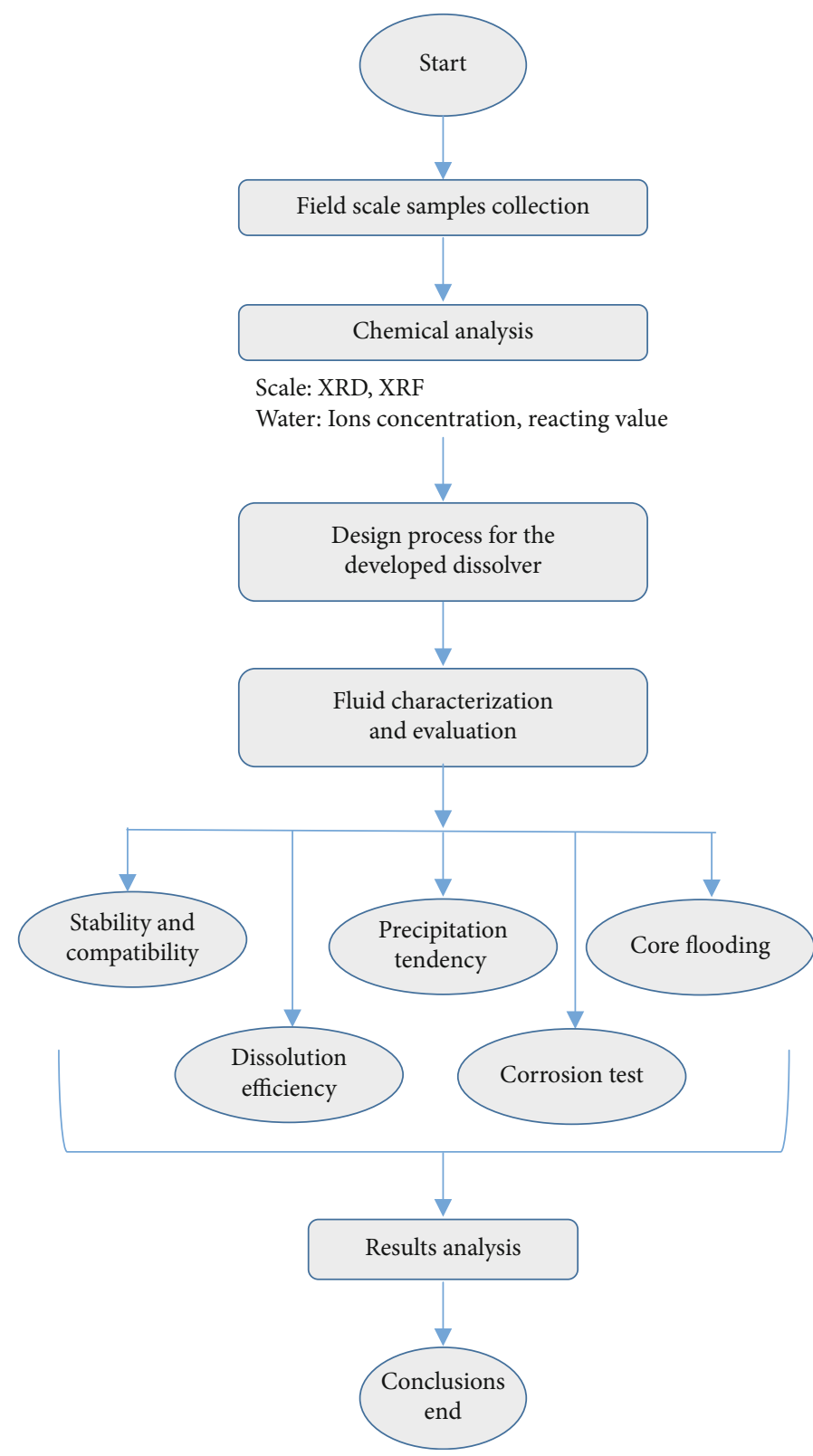

FIgURE 1: The methodology layout for the study.

samples from the production and injection streams, and then, the design process for the developed dissolver for the barium sulfate scale. The fluid characterization and evaluation were performed by extensive lab work in terms of the fluid compatibility and stability, solution efficiency, precipitation tendency, corrosion test, and the core flooding experiment. The test results were analyzed and conclusions were provided based on these results analysis.

2.1. Materials Description. The main objective of this study is to provide a solution for removing the field barium sulfate scales. In this study, two scale samples of barium sulfate type were collected from a real production field that has scale precipitation issues. The first scale was collected from an offshore producing platform, whereas the second one was collected from a pipeline that is used for petroleum transpor- tation in the oil field. Figure 2 shows the collected scale samples to be prepared for the chemical and physical analysis to study their properties and compositions. Scale sample 1 (Figure 2(a)) was collected from a producing oil well that has wellhead pressure of $5.86 \mathrm{MPa}$ and downhole pressure of $14.96 \mathrm{MPa}$, associated water cut of $85 \%$, reservoir depth of $2,050 \mathrm{~m}$, and average surface temperature of $35^{\circ} \mathrm{C}$. The second scale sample (Figure 2(b)) was collected from a surface pipeline network that has a temperature of $35^{\circ} \mathrm{C}$.

The collected scale samples were investigated employing $\mathrm{X}$-ray diffraction (XRD) and X-ray fluorescence (XRF) to determine the mineralogical and elemental compositions of the scale samples [46]. Table 1 listed the XRD results for the two samples, sample 1 had $100 \%$ barium sulfate $\left(\mathrm{BaSO}_{4}\right)$, while sample 2 had barium sulfate of $97.75 \%$ and $2.25 \%$ quartz $\left(\mathrm{SiO}_{2}\right)$. The elemental composition of the scale 


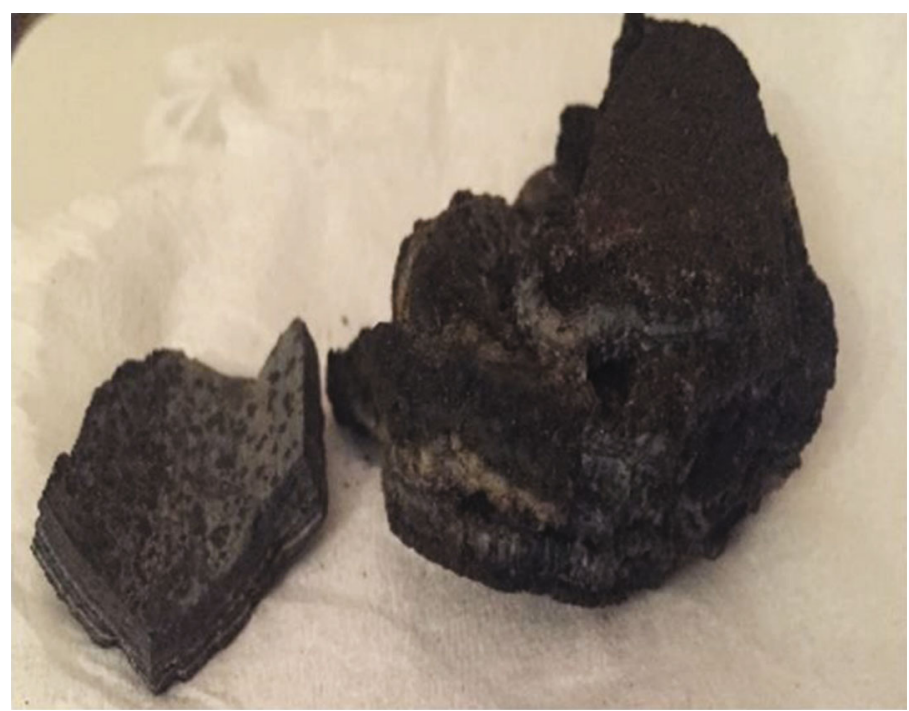

(a)

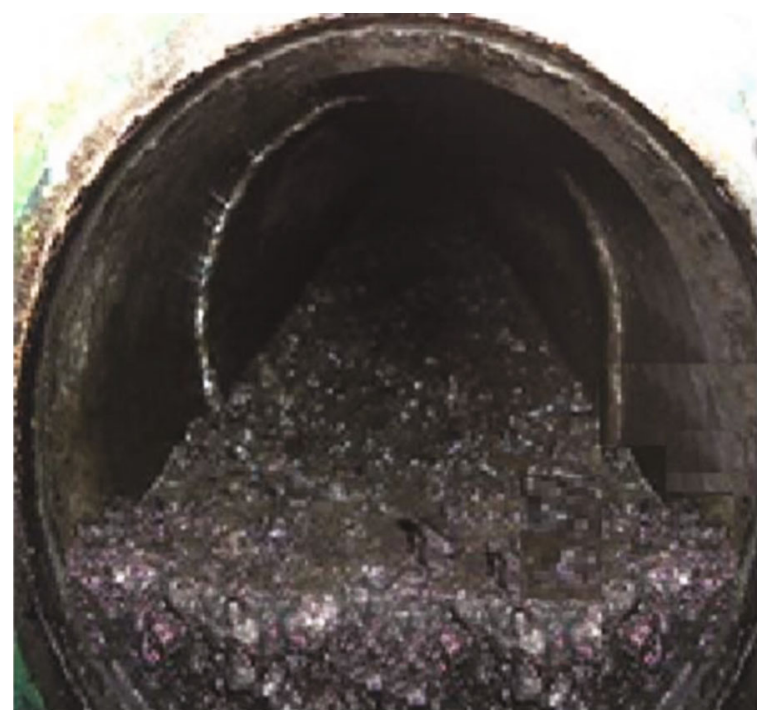

(b)

Figure 2: Barium sulfate samples from the field. (a) Collected from a platform. (b) Collected from a transportation pipeline.

TABLE 1: XRD results for the collected barium scale samples.

\begin{tabular}{lccc}
\hline Compound & $\begin{array}{c}\text { Chemical } \\
\text { formula }\end{array}$ & $\begin{array}{c}\text { Sample 1, } \\
\text { wt.\% }\end{array}$ & $\begin{array}{c}\text { Sample 2, } \\
\text { wt.\% }\end{array}$ \\
\hline $\begin{array}{l}\text { Barium } \\
\text { sulfate }\end{array}$ & $\mathrm{BaSO}_{4}$ & 100 & 97.75 \\
$\begin{array}{l}\text { Quartz } \\
\text { Total }\end{array}$ & $\mathrm{SiO}_{2}$ & 0 & 2.25 \\
& & 100 & 100 \\
\hline
\end{tabular}

samples showed that they are mainly composed of sulfur (S) and barium $(\mathrm{Ba})$ elements as samples 1 and 2 had a barium content of 48.4 and $44.6 \%$ and a sulfur element of 17.7 and 14.1 wt.\%, respectively (Table 2 ). The composition included an additional small amount of silicon, chloride, and strontium elements.

The chemical analysis of the water is very critical as the formation of scales is highly dictated by its composition. The analysis for the produced water sample from the field was performed, and Table 3 shows the ions concentrations and the relevant reacting value for each ion. The reacting value is important from a chemical point of view to predict the scale type [30]. The results showed that chloride, barium, and sodium have the highest ion concentrations by 61,900 , 38,500 , and 31,400 milligrams/liter $(\mathrm{mg} / \mathrm{L})$, respectively, and these ions have the highest percentages for the reacting values by $49.3,48.04$, and $38.6 \%$, respectively. Sulfate $\left(\mathrm{SO}_{4}\right)$ concentration is $926 \mathrm{mg} / \mathrm{L}$ in the produced water sample. The specific gravity for the developed solution was 1.048. The chemical analysis was also performed on the injected water that was used for the enhanced recovery. Table 4 shows the chemical analysis of the water sample that was used for the injection operations in the field. The results show that chloride, sodium, and sulfate represent the highest ions concentration in the injected water with concentrations of $19,162,10,679$, and $2,680 \mathrm{mg} / \mathrm{L}$, respectively. The total dis- solved solids were found to be $35,556.5 \mathrm{mg} / \mathrm{L}$ ( $\mathrm{ppm}$ ) for the injected water sample, while it was 101,843 ppm for the produced water sample.

The study proposed a newly developed barium sulfate scale dissolver at a low-temperature scale. Table 5 shows the chemical composition for the proposed dissolver. Diethylenetriamine pentaacetic acid (DTPA) with 15 to 30 weight percentage was employed as a chelating agent, oxalic acid and tannic acids as an activator for the new chemical dissolver with concentrations of (5 to 15 ) and (1 to 5) wt.\%, respectively, less than $1 \mathrm{wt} . \%$ of nonionic surfactant, and water as the base fluid constituting the remaining weight percentage. The developed barium sulfate scale dissolver had a $\mathrm{pH}$ of 9.78 and 1.17 specific gravity at ambient conditions.

\section{Experimental Lab Work}

The experimental lab work was designed to investigate the developed dissolver for application aspects in terms of compatibility and stability, dissolution performance at specific conditions of temperature and time, precipitation tendency of the dissolved solids, and core flooding test. The following section will discuss in detail the procedures for each lab test.

3.1. Fluid Stability and Compatibility. The fluid stability might change with the ambient conditions, and therefore, testing fluid stability is very critical as it represents the fluid resistance to change with changing the conditions. The test was conducted as follows:

(i) A fluid amount $(100 \mathrm{ml})$ was put into a flask, and stirring the fluid for $10 \mathrm{~min}$

(ii) Cover the fluid flask and put it into a static oven or on a Hot-plate at $150^{\circ} \mathrm{C}$ for 24 hours

(iii) Examine the fluid for any color changes and/or precipitations 
TABLE 2: XRF results for the collected barium scale samples.

\begin{tabular}{lccc}
\hline Element & Chemical formula & Sample 1 (wt.\%) & Sample 2 (wt.\%) \\
\hline Silicon & $\mathrm{Si}$ & 0.0 & 2.82 \\
Sulfur & $\mathrm{S}$ & 17.7 & 14.1 \\
Chloride & $\mathrm{Cl}$ & 0.7 & 0.2 \\
Barium & $\mathrm{Ba}$ & 48.4 & 44.6 \\
Strontium & $\mathrm{Sr}$ & 0.0 & 0.35 \\
\hline
\end{tabular}

TABLE 3: Chemical analysis results for the field produced water.

\begin{tabular}{lcccc}
\hline Ions & $\begin{array}{c}\text { Chemical } \\
\text { formula }\end{array}$ & $\mathrm{mg} / \mathrm{L}$ & $\begin{array}{c}\text { Reacting } \\
\text { value }\end{array}$ & $\begin{array}{c}\text { \% reacting } \\
\text { value }\end{array}$ \\
\hline Sodium & $\mathrm{Na}$ & 31,400 & $1,366.72$ & 38.60 \\
Calcium & $\mathrm{Ca}$ & 6,030 & 300.90 & 50 \\
Barium & $\mathrm{Ba}$ & 38,500 & $1,085.70$ & 48.04 \\
Magnesium & $\mathrm{Mg}$ & 1,250 & 102.75 & 2.90 \\
Sulfate & $\mathrm{SO}_{4}$ & 926 & 19.26 & 0.54 \\
Chloride & $\mathrm{Cl}_{\text {Carbonate }}$ & 61,900 & $1,745.58$ & 49.30 \\
Bicarbonate & $\mathrm{CO}_{3}$ & 0.00 & 0.00 & 0.00 \\
Hydroxide & $\mathrm{OH}$ & 337 & 5.53 & 0.16 \\
Total dissolved solids & 101,843 & 0.00 & 0.00 \\
\hline
\end{tabular}

TABLE 4: Chemical analysis results for the field injected water.

\begin{tabular}{lcc}
\hline Ions & Chemical formula & $\mathrm{mg} / \mathrm{L}$ \\
\hline Chloride & $\mathrm{Cl}$ & 19,162 \\
Sodium & $\mathrm{Na}$ & 10,679 \\
Magnesium & $\mathrm{Mg}$ & 1,278 \\
Sulfate & $\mathrm{SO}_{4}$ & 2,680 \\
Calcium & $\mathrm{Ca}$ & 409.6 \\
Potassium & $\mathrm{K}$ & 395.3 \\
Carbon (inorganic) & $\mathrm{C}$ & 276 \\
Bromide & $\mathrm{Br}$ & 663 \\
Boron & $\mathrm{B}$ & 4.4 \\
Strontium & $\mathrm{Sr}$ & 7.9 \\
Fluoride & $\mathrm{F}$ & 1.3 \\
Total dissolved solids & & $35,556.5$ \\
\hline
\end{tabular}

(iv) Record photos before and after the test in a clear glass tube

Also, the fluid compatibility was tested by two processes of mixing the developed scale dissolver with samples of the formation water and crude oil individually for each sample. The mixing was performed by 50 to $50 \%$ of the developed dissolver and the field sample (formation water for test 1 and crude oil for test 2). After that, the mixed solution was kept at $150^{\circ} \mathrm{C}$ for 24 hours and the solution was investigated for any physical changes in color, precipitation, or phase separation.
TABLE 5: The chemical composition of the new scale dissolver.

\begin{tabular}{lcc}
\hline Component & wt. $\%$ & Function \\
\hline DTPA & $15 \sim 30$ & Chelating agent \\
Oxalic acid & $5 \sim 15$ & Activator \\
Tannic acid & $1 \sim 5$ & Activator \\
Nonionic surfactant & $<1$ & Penetrant \\
Water & $60 \sim 68$ & Base fluid \\
\hline
\end{tabular}

3.2. Solubility Test. The solubility test is commonly studied to report the dissolution efficiency of the developed chemical dissolver for the scale sample by calculating the weight decrease of the scale before and after the exposure to the developed dissolver. The test was conducted several times to determine the optimum scale mass to dissolver volume ratio for the assessment of the economic and technical aspects $[19,47]$. The high efficient dissolver should provide a high dissolution rate with lesser dissolver volume 5 . The prospected mass of the precipitated scale is typically calculated by the reduction in the inner diameter of the equipment that has a precipitated scale and the scale density value [14, 48]. The test procedures were conducted under two temperature levels of 35 and $90^{\circ} \mathrm{C}$ at atmospheric pressure for 24 hours as follows:

(i) $100 \mathrm{ml}$ of the developed scale dissolver was placed in an oven at the required temperature for $10 \mathrm{~min}$

(ii) $10 \mathrm{~g}\left[\mathrm{~W}_{1}\right]$ of the scale sample was measured

(iii) The solid scale was added to the dissolver solution in the test tube

(iv) Once the test period was up, commence removing the test bottle to cool down in a water bath

(v) The weight of the filter paper $\left[W_{f}\right]$ was measured and then filtered using a vacuum filter

(vi) The remaining solid was dried in a static oven at $90^{\circ} \mathrm{C}$ for 2.5 hours

(vii) The weight after the drying process (weight of filter paper with the remaining solids) $\left[W_{2}\right]$ was measured

(viii) The weight of the remaining solids was calculated $\left[\mathrm{W}_{3}=\mathrm{W}_{2}-\mathrm{W}_{\mathrm{f}}\right]$

(ix) The dissolution capacity was calculated as $\left[\left[\mathrm{W}_{1}-\right.\right.$ $\left.\left.\mathrm{W}_{3}\right] / \mathrm{W}_{1}\right] * 100$

3.3. Precipitation Tendency for Dissolved Solids. The term precipitation tendency for dissolved solids represents the tendency of the dissolver scale solids to precipitate after the dissolution impact of the scale dissolver during the descale treatment operation. During the solubility test, some scale solids dissolved in the chemical solution of the dissolver. Such dissolved solids can precipitate due to the change in conditions of pressure, temperature, and/or time. The precipitation of dissolved solids is a critical issue that can lead 
to equipment plugging or generating another scale type. The test simulates the real-field environment for the descale jobs and reports how much of the dissolved scale solids will precipitate after the treatment. The precipitation tendency test of the dissolved solids was performed to check for that. The test was conducted at a low temperature of $35^{\circ} \mathrm{C}$ for 24 hours on the two collected scale samples.

3.4. Corrosion Test. Corrosion is considered a big issue in field operations that is partially or completely damages the field or well equipment. The corrosion test was conducted to calculate the corrosion rate of the dissolver at $50^{\circ} \mathrm{C}$ for 6 hours (which is adequate for descale operation) [19] using an autoclave cell at a pressure of 6.9 MPa. The developed dissolver solution was tested for corrosion without any corrosion inhibitors by using a casing coupon of T95 grade. The weight reduction of the coupon was measured after the corrosion test to determine the corrosion rate as follow [49]:

$$
\mathrm{CR}=\frac{W_{l}}{A * T}
$$

where CR is the corrosion rate $\left[\mathrm{mg} /\left(\mathrm{cm}^{2} \mathrm{hr}.\right)\right], W_{l}$ is the loss of coupon weight (mg), $A$ is the initial surface area of the coupon $\left(\mathrm{cm}^{2}\right)$, and $T$ is the exposure time (hr.).

3.5. Core Flooding Experiment. In order to determine the efficiency of the newly developed dissolver, a core sample was initially flooded with oil-based mud (OBM) that was weighted by barite (barium sulfate) as a weighting material. Table 6 shows the OBM composition with the mud additives and their quantities to prepare one barrel for the mud. Diesel is the base fluid for the mud with 93.8 liters and barite represents the mud weighting material with $72.6 \mathrm{~kg}$ to control the mud density, and the other compositions were commonly added for adjusting the mud rheology and filtration properties. Table 7 shows the mud rheological properties in terms of yield point and plastic viscosity and the filtration properties of the mud. The mud density was 1.68 grams per cubic centimeter $\left(\mathrm{g} / \mathrm{cm}^{3}\right)$, the mud yield point was 7.182 Pascal, and the viscosity was 0.063 Pascal second (Pa.s). The measurements were under a temperature of $50^{\circ} \mathrm{C}$, while the mud filtration was 3.2 cubic centimeters per 30 minutes at a temperature of $180^{\circ} \mathrm{C}$.

The developed scale dissolver was investigated for the core flooding test by employing a core sample of Berea sandstone rock type. Figure 3 showed a schematic diagram for the core flooding apparatus. Table 8 shows the core properties and the flooding experiment conditions. The core sample had $12.29 \%$ porosity and $78.88 \mathrm{mD}$ permeability. The core flooding was conducted at $90^{\circ} \mathrm{C}$ with net overburden pressure of $3.45 \mathrm{MPa}$.

The test was conducted as per the following procedures:

(1) The core initial permeability was determined

(2) $200 \mathrm{ml}$ of the prepared OBM to simulate the real formation damage by the barite was injected
TABLE 6: OBM composition (one barrel).

\begin{tabular}{lc}
\hline Material & Quantity \\
\hline Diesel & $93.8 \mathrm{~L}$ \\
Barite & $72.6 \mathrm{~kg}$ \\
Lime & $550 \mathrm{~g}$ \\
Calcium chloride 98\% & 1.93 \\
Caustic soda & $240 \mathrm{~g}$ \\
Salt & $380 \mathrm{~g}$ \\
Soda ash & $68 \mathrm{~g}$ \\
Sodium bicarbonate & $228 \mathrm{~g}$ \\
XC polymer & $437 \mathrm{~g}$ \\
\hline
\end{tabular}

TABLE 7: OBM mud properties.

\begin{tabular}{lc}
\hline Density & $1.68 \mathrm{~g} / \mathrm{cm}^{3} @ 50^{\circ} \mathrm{C}$ \\
\hline Yield point & $7.182 \mathrm{Pascal}(\mathrm{Pa}) @ 50^{\circ} \mathrm{C}$ \\
Viscosity & $0.063 \mathrm{Pascal} \mathrm{second} \mathrm{(Pa.s)} \mathrm{@} 50$ \\
Filtration & $3.2 \mathrm{~cm}^{3} / 30 \mathrm{~min} @ 180^{\circ} \mathrm{C}$ \\
\hline
\end{tabular}

(3) The core was displaced by $200 \mathrm{ml}$ of $5 \% \mathrm{NH}_{4} \mathrm{Cl}$ (preflush stage)

(4) The permeability was measured at the same injection rates $(1-2 \mathrm{ml} / \mathrm{min})$

(5) The core was displaced by $100 \mathrm{ml}$ of the developed scale dissolver and left to soak for 3 hours (main treatment)

(6) The plug was displaced by $200 \mathrm{ml}$ of $5 \% \mathrm{NH}_{4} \mathrm{Cl}$ (postflush stage)

(7) The permeability was measured at the same injection rates $(1-2 \mathrm{ml} / \mathrm{min})$

The return permeability was determined from steps 3 and 6 to get the core permeability before and after the treatment using the developed scale dissolver.

$$
\operatorname{return} \mathrm{K}=\frac{k_{f}}{K_{i}}
$$

where return $\mathrm{K}$ is the return permeability value in (\%), $k_{f}$ is the final permeability $(\mathrm{mD})$, and $k_{i}$ is the initial permeability $(\mathrm{mD})$.

\section{Results and Discussion}

4.1. Fluid Stability and Compatibility. The developed dissolver was tested for fluid stability and compatibility under conditions of $150^{\circ} \mathrm{C}$ for 24 hours. The results showed no color change and no precipitation as showed in Figure 4.

4.2. Solubility Results. The dissolution rate was investigated to determine the scale removal efficiency for the field descale operations. The results are presented in Figure 5. They revealed a high efficiency of 76.9 and $71.2 \%$ for sample 1 


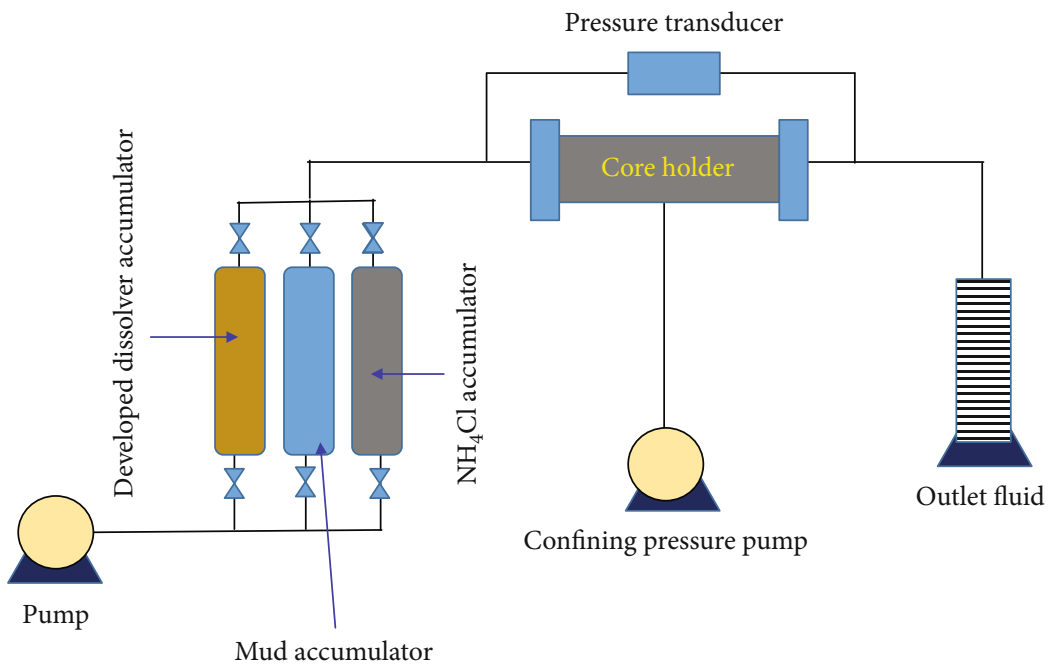

FIgURE 3: Flooding apparatus schematic.

TABLE 8: Core flooding experiment conditions.

\begin{tabular}{lc}
\hline Core type & Berea sandstone \\
\hline Core porosity & $12.29 \%$ \\
Core permeability & $7.78 \mathrm{E}-10 \mathrm{~cm}^{2}(78.88 \mathrm{mD})$ \\
$\left(\mathrm{mD}, 9.869 \mathrm{E}^{-12} \mathrm{~cm}^{2}\right)$ & $7.62 \mathrm{~cm}$ length $(3$ inches $)$ \\
Core dimensions & $3.81 \mathrm{~cm}$ diameter $(1.5$ inches $)$ \\
(inches, $2.54 \mathrm{~cm})$ & $90^{\circ} \mathrm{C}$ \\
Temperature & $3.45 \mathrm{MPa}$ \\
Net overburden pressure & $6.9 \mathrm{MPa}$ \\
Back pressure & \\
\hline
\end{tabular}

and 91.3 and $78.4 \%$ for sample 2 at $35^{\circ} \mathrm{C}$ and $90^{\circ} \mathrm{C}$, respectively. As shown the solubility test was conducted at two levels for temperatures at $35^{\circ} \mathrm{C}$ and $90^{\circ} \mathrm{C}$ to account for the surface (low temperature) and downhole (high temperature) conditions for the scale precipitations.

Also, the dissolution efficiency was compared with other dissolver solutions to show the relative improvement in the performance. $\mathrm{HCl}$ acid (15wt.\%), EDTA (20wt.\%), and DTPA (20 wt.\%) were employed for this comparison, and the results showed that the developed dissolver showed a significant improvement of dissolution efficiency for the two samples. As presented in Figure 6, $\mathrm{HCl}(15 \mathrm{wt} . \%)$ showed a weak dissolution for the two scale samples by 1.3 and $1 \%$ for samples 1 and 2, respectively. EDTA (20wt.\%), and DTPA (20 wt.\%) had a close performance; however, it is not strong dissolution as the results were 21.2 and $12.9 \%$ for EDTA (20wt.\%) and 27.8 and $15.6 \%$ for DTPA (20wt.\%) for samples 1 and 2, respectively. The developed dissolver outperformed the EDTA (20 wt.\%) and DTPA (20 wt.\%) with an average factor of 3.2 and 5 for the dissolution rates, respectively.

4.3. Precipitation Tendency for Dissolved Solids. Figure 7 shows the results of the precipitation tendency test for dissolved solids for 24 hours at $35^{\circ} \mathrm{C}$. The results indicated that

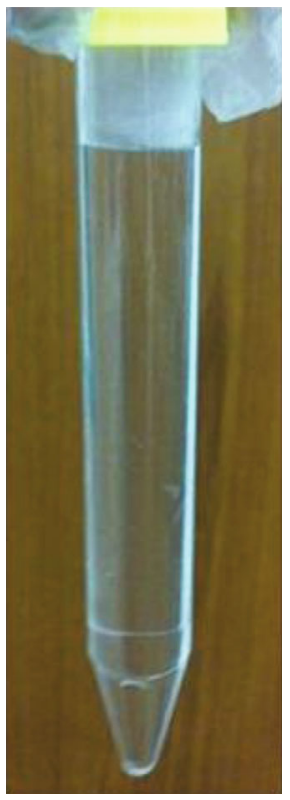

(a)

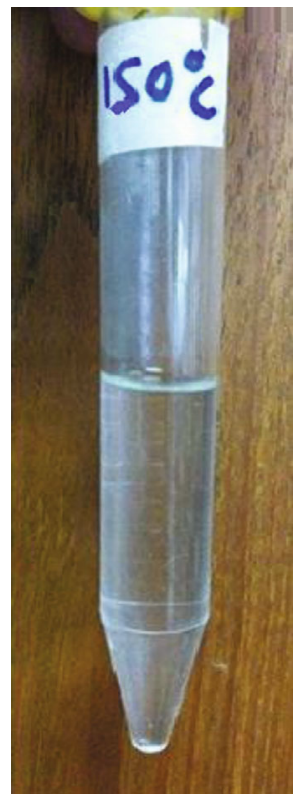

(b)
FIgURE 4: Stability performance. (a) At room temperature. (b) After 24 hours at $150^{\circ} \mathrm{C}$

for scale sample 1, the precipitation tendency test for dissolved solids was $1.9 \%$ and $3.2 \%$ for scale sample 2 . The low precipitation tendency for the dissolved solids showed a good dissolution performance without the precipitations of the dissolved solids again after the treatment operations.

\section{Corrosion Test}

The results for the corrosion test revealed an additional advantage of the developed dissolver. Table 9 listed the corrosion test results for the steel coupon before and after the exposure to the new dissolver at a pressure of 6.9 MPa under 


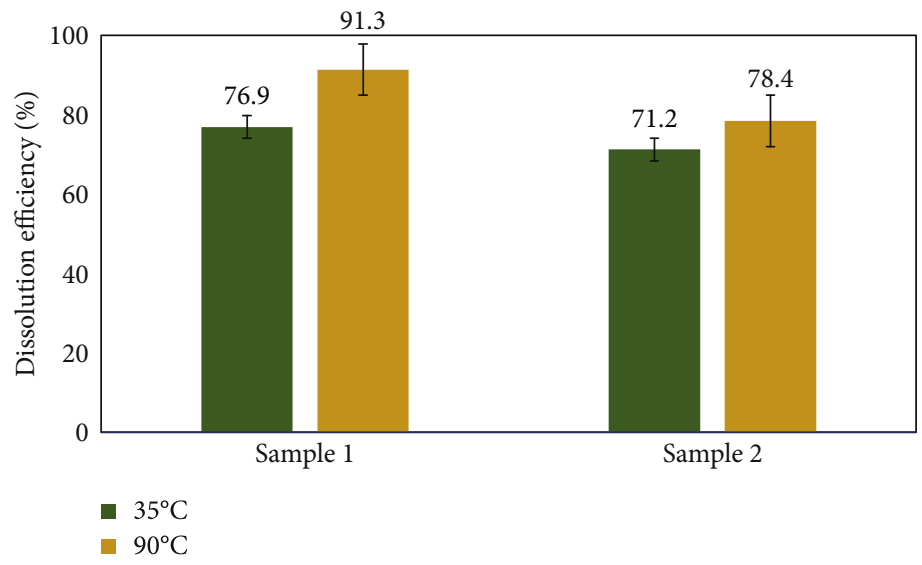

Figure 5: Dissolution efficiency for the developed dissolver at different temperatures $\left(35^{\circ} \mathrm{C}\right.$ and $90^{\circ} \mathrm{C}$ for 24 hours).

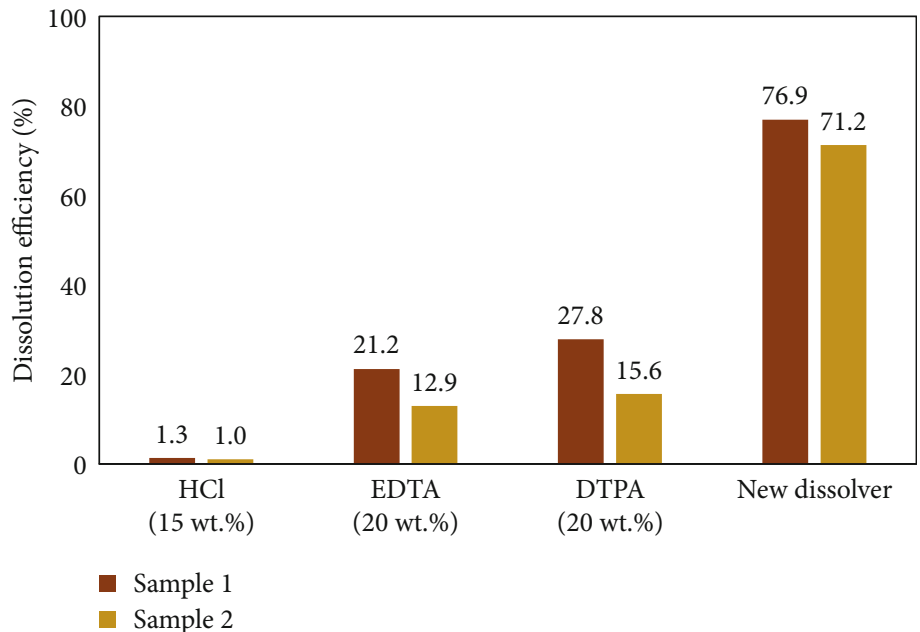

Figure 6: Dissolution efficiency for the developed dissolver versus commercial ones at $35^{\circ} \mathrm{C}$ for 24 hours.

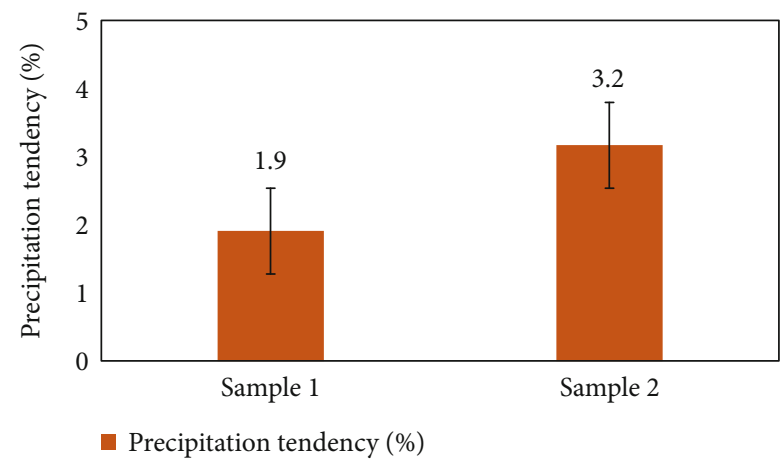

FIGURE 7: Results of precipitation tendency for dissolved solids for the two scale samples.

TABLE 9: Corrosion test results.

\begin{tabular}{lcccc}
\hline Condition & $\begin{array}{c}\text { Weight, } \\
\mathrm{g}\end{array}$ & $\begin{array}{c}\text { Surface area, } \\
\mathrm{cm}^{2}\end{array}$ & $\begin{array}{c}\text { Thickness, } \\
\mathrm{cm}\end{array}$ & $\begin{array}{c}\text { Corrosion rate, } \\
\mathrm{g} / \mathrm{cm}^{2}\end{array}$ \\
\hline Before & 51.726 & 50.73457 & 0.30198 & 0.001835 \\
After & 47.323 & 50.68792 & 0.29946 & \\
\hline
\end{tabular}

$50^{\circ} \mathrm{C}$ for 6 hours. The results showed that the surface area reduced by only $0.0919 \%$ after the exposure while there was a thickness reduction by $0.834 \%$ to provide a corrosion rate of $0.001835 \mathrm{~g} / \mathrm{cm}^{2}$ which is very low and indicates the safe use of the developed dissolver for removing the barium sulfate scales.

5.1. Core Flooding. Flooding the damaged sandstone core sample with the developed scale dissolver was executed as per the test procedures and the results are presented in Figure 8 . The core flooding experiment started by pumping the developed dissolver into the damaged sandstone core plug at $36 \mathrm{kPa}$, and the pressure started to increase by the pumping force action into the pore system of the damaged core sample until the wormholes were initiated by the chemical reaction impact between the rock-dissolver at $48 \mathrm{kPa}$ after injecting $5.25 \mathrm{ml}$ of the dissolver solution. The initiated wormholes were then propagated, and the differential pressure started to decrease due to increasing the reaction rate between the rock matrix and the scale dissolver. Figure 9 shows the generated wormholes in the flooded core sample after pumping the dissolver fluid. 


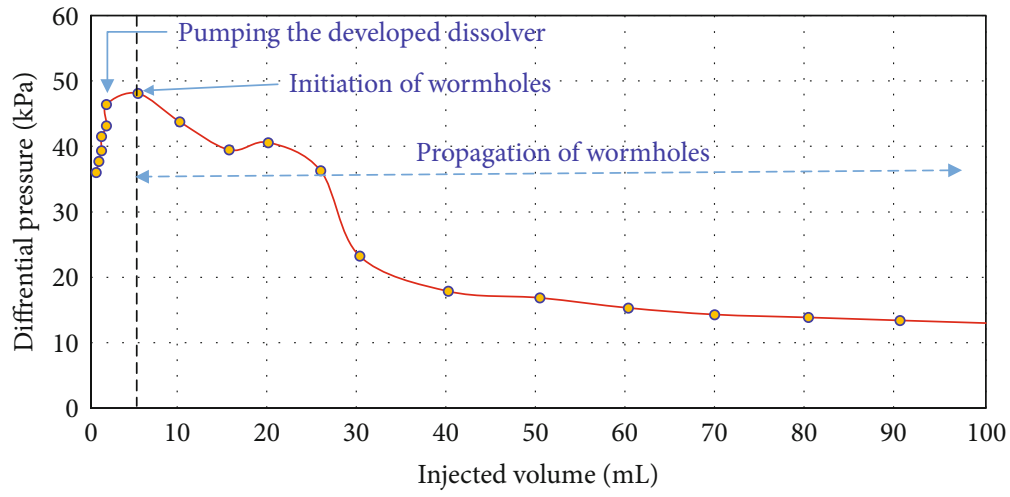

FIgURE 8: Pressure drop versus injected volume during injecting with the developed dissolver.

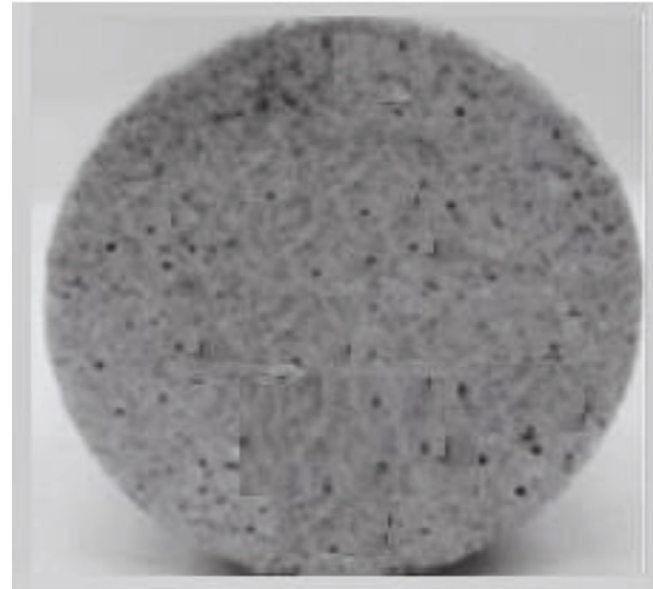

(a)

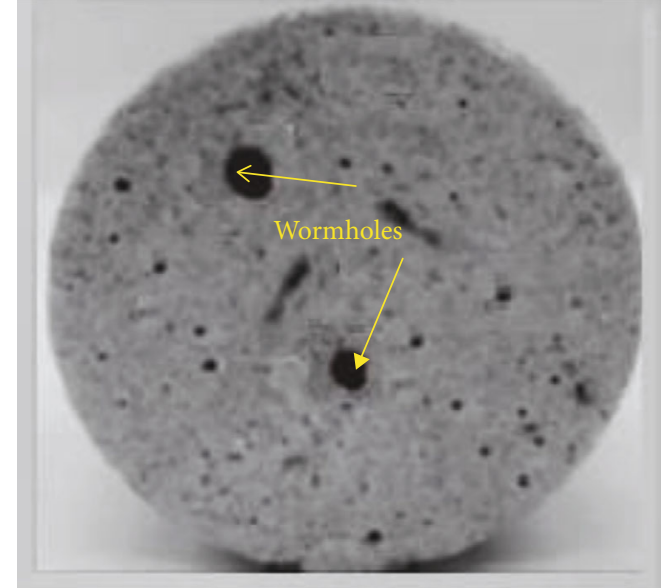

(b)

Figure 9: Core sample for core flooding. (a) Sample before flooding. (b) Wormholes after injecting the new dissolver.

The permeability of the core sample was determined before and after the core flooding experiment using the developed dissolver. The results showed that the permeability value was improved from $47.75 \mathrm{mD}$ to $54.68 \mathrm{mD}$ after injecting the new solution of the developed barium sulfate scale dissolver (i.e., the return permeability was 115\%). The results indicated a satisfactory performance of the newly developed dissolver to remove the damage that was caused by the barrier OBM and returned the original rock permeability with enhancement, and therefore, the results provide a promising potential of the dissolver for the field treatment application.

5.2. Dissolution Mechanism. The newly developed scale dissolver has diethylenetriamine pentaacetic acid (DTPA) as a chelating agent, oxalic acid and tannic acids as an activator, and nonionic surfactant. The developed composition was designed to provide the high dissolution performance of barium sulfate scales that was achieved as follows:

(i) DTPA: is a chelation agent complexing the barium and silicon compounds in the scale and the core plug

(ii) Oxalic Acid: classified as the simplest dicarboxylic acid. Its acid strength is much greater than that of acetic acid [48]. Oxalic acid is a reducing agent and its conjugate base is a chelating agent for metal cations

(iii) Tannic Acid: works as an activator, cleaning agent as a surfactant, reacts with corrosion products, and reacts as a corrosion inhibitor

(iv) Nonionic Surfactant: nonionic surfactants contain no charge, they are the second most widely used surfactants after anionic surfactant, these molecules have no charge and so they are less likely to create foam, nonionic surfactant can work on both carbonate and sandstone formations

\section{Conclusions}

This study proposed a newly developed dissolver that showed a promising potential for removing barium sulfate scale with high dissolution efficiency, low precipitation tendency, low corrosion rate, and permeability enhancement for sandstone core flooding experiment. The following findings summarize the lab investigation of the developed dissolver:

(i) The fluid showed good stability and compatibility under temperature conditions of $150^{\circ} \mathrm{C}$ for 24 hours 
(ii) The dissolution efficiency was high for the two barium sulfate scale samples, at $35^{\circ} \mathrm{C}$, the dissolution was 76.9 and $71.2 \%$, while at $90^{\circ} \mathrm{C}$, the results were 91.3 and $78.4 \%$ for sample 1 and 2, respectively

(iii) The solubility efficiency for the developed dissolver outperformed the other common chemical dissolvers for scale removal as $\mathrm{HCl}$ acid (15 wt.\%), EDTA (20 wt.\%), and DTPA (20 wt.\%).

(iv) The precipitation tendency test for the dissolved solids showed that dissolved solids were 1.9 and $3.2 \%$ for the scale samples 1 and 2, respectively, under $35^{\circ} \mathrm{C}$ for 24 hours

(v) The developed scale dissolver had a safe corrosion rate $\left(0.001835 \mathrm{~g} / \mathrm{cm}^{2}\right)$ without any corrosion inhibitor additives

(vi) The core flooding test provided a $115 \%$ return permeability of the damaged sandstone sample

The limitations beyond this study can be summarized in the scale mineralogy, pressure and temperature environment, solubility static condition, and sandstone as a rock type for core flooding experiment. The obtained results from this study indicated a safe use and a great performance for field descale applications to remove the barium sulfate scale.

$\begin{array}{ll}\text { Abbreviations } \\ \text { XRD: } & \text { X-ray diffraction } \\ \text { XRF: } & \text { X-ray fluorescence } \\ \text { HCl: } & \text { Hydrochloric acid } \\ \text { EDTA: } & \text { Ethylenediaminetetraacetic acid } \\ \text { DTPA: } & \text { Diethylenetriamine pentaacetic acid } \\ \text { HEDTA: } & \text { Hydroxyethyl ethylene diamine triacetic acid } \\ \text { HIDA: } & \text { Hydroxyethyl iminodiacetic acid } \\ \text { NTA: } & \text { Nitrilotriacetic acid } \\ \text { MGDA: } & \text { Methylglycinediacetic acid } \\ \text { mD: } & \text { Millidarcy } \\ \text { THPS: } & \text { Tetrakis hydroxymethyl phosphonium salts } \\ \text { HPHT: } & \text { High-pressure high-temperature } \\ \text { T95: } & \text { Casing grade } \\ \text { CR: } & \text { Corrosion rate }\left[\mathrm{mg} /\left(\mathrm{cm}^{2} \text { hr. }\right)\right] \\ W_{l}: & \text { Weight loss (mg) } \\ \text { A: } & \text { Initial surface area of the coupon }\left(\mathrm{cm}^{2}\right) \\ \text { T: } & \text { Exposure time (hr.) } \\ \text { MPa: } & \text { Mega Pascal } \\ \text { kPa: } & \text { Kilo Pascal } \\ \text { mg/l: } & \text { Milligrams per liter } \\ \text { ml: } & \text { Milliliter } \\ \text { g: } & \text { Gram. }\end{array}$

\section{Data Availability}

The data is already included in the manuscript.

\section{Conflicts of Interest}

The authors declare no conflicts of interest.

\section{Acknowledgments}

The authors wish to acknowledge King Fahd University of Petroleum \& Minerals and Rosewell Energy company for their permission to publish this work.

\section{References}

[1] M. A. Kasnick and R. J. Engen, "Iron sulfide scaling and associated corrosion in Saudi Arabian Khuff Gas wells," in Presented at the SPE Middle East Oil Technical Conference and Exhibition, Manama, Bahrain, March 1989.

[2] M. Crabtree, D. Eslinger, P. Fletcher, M. Miller, A. Johnson, and G. King, "Fighting scale - removal and prevention," Oilfield Review, vol. 11, no. 3, pp. 30-45, 1999.

[3] T. Chen, H. Montgomerie, P. Chen, T. H. Hagen, and S. J. Kegg, "Development of environmental friendly iron sulfide inhibitors for field application," in Presenced at the International Symposium on Oilfield Chemistry, The Woodlands, TX, USA, April 2009.

[4] M. S. Kamal, I. Hussein, M. Mahmoud, A. S. Sultan, and M. A. Saad, "Oilfield scale formation and chemical removal: a review," Journal of Petroleum Science and Engineering, vol. 171, pp. 127-139, 2018.

[5] S. Elkatatny, "New formulation for iron sulfide scale removal," in Presenced at the Middle East Oil and Gas Show and Conference, Manama, Bahrain, March 2017.

[6] M. Bader, "Sulfate removal technologies for oil fields seawater injection operations," Journal of Petroleum Science and Engineering, vol. 55, no. 1-2, pp. 93-110, 2007.

[7] A. B. Bin Merdhah, A. A. M. Yassin, and M. A. Muherei, "Laboratory and prediction of barium sulfate scaling at highbarium formation water," Journal of Petroleum Science and Engineering, vol. 70, no. 1-2, pp. 79-88, 2010.

[8] J. Li, T. Li, J. Yan, X. Zuo, Y. Zheng, and F. Yang, "Silicon-containing scale forming characteristics and how scaling impacts sucker rod pump in ASP flooding," in Paper presented at the Asia Pacific Oil and Gas Conference Exhibition, Jakarta, Indonesia, August 2009.

[9] B. Senthilmurugan, B. Ghosh, and S. Sanker, "High-performance maleic acid-based oil well scale inhibitors-development and comparative evaluation," Journal of Industrial and Engineering Chemistry, vol. 17, no. 3, pp. 415-420, 2011.

[10] J. Yap, M. J. Fuller, L. Schafer, and S. K. Kelkar, "Removing iron sulfide scale: a novel approach," in Paper presented at the Abu Dhabi International Petroleum Exhibition and Conference, Abu Dhabi, UAE, November 2010.

[11] G. V. Chilingar, R. Mourhatch, and G. D. Al-Qahtani, The Fundamentals of Corrosion and Scaling for Petroleum and Environmental Engineers, Elsevier, 2013.

[12] S. Basfar, A. Mohamed, and S. Elkatatny, "Barite-Micromax mixture, an enhanced weighting agent for the elimination of barite sag in invert emulsion drilling fluids," Journal of Petroleum Exploration and Production Technologies, vol. 10, no. 6, pp. 2427-2435, 2020.

[13] B. Bageri, M. Mahmoud, R. Shawabkeh, S. Al-Mutairi, and A. Abdulraheem, "Toward a complete removal of barite (barium sulfate $\mathrm{BaSO}_{4}$ ) scale using chelating agents and catalysts," Arabian Journal for Science and Engineering, vol. 42, no. 4, pp. 1667-1674, 2017. 
[14] H. Gamal, S. Elkatatny, A. Abdulraheem, and A. Al Majed, "Exposure time impact on the geomechanical characteristics of sandstone formation during horizontal drilling," Molecules, vol. 25, no. 11, p. 2480, 2020.

[15] H. Gamal, S. Elkatatny, A. Adebayo, and B. Bageri, "Effect of exposure time on the compressive strength and formation damage of sandstone while drilling horizontal wells," Journal of Petroleum Science and Engineering, vol. 195, p. 107590, 2020.

[16] H. Gamal, S. Elkatatny, and A. Abdulraheem, "Effect of the filtrate fluid of water-based mud on sandstone rock strength and elastic moduli," ACS Omega, vol. 5, no. 50, pp. 32677-32688, 2020.

[17] J. Oddo, J. Smith, and M. Tomson, "Analysis of and solutions to the $\mathrm{CaCO} 3$ and $\mathrm{CaSO} 4$ scaling problems encountered in wells offshore Indonesia," in Paper presented at the SPE Annual Technical Conference and Exhibition, Dallas, TX, USA, October 1991.

[18] M. A. Mahmoud, "Evaluating the damage caused by calcium sulfate scale precipitation during low and high-salinity-water injection," Journal of Canadian Petroleum Technology, vol. 53, no. 3, pp. 141-150, 2014.

[19] T. Chen, Q. Wang, F. F. Chang, and Y. T. Al-Janabi, "New developments in iron sulfide scale dissolvers," in NACE International Corrosion Conference Proceedings, Houston, TX, USA, March 2016.

[20] H. Gamal, K. Abdelgawad, and S. Elkatatny, "New environmentally friendly acid system for Iron sulfide scale removal," Sustainability, vol. 11, no. 23, p. 6727, 2019.

[21] A. A. Olajire, "A review of oilfield scale management technology for oil and gas production," Journal of Petroleum Science and Engineering, vol. 135, pp. 723-737, 2015.

[22] H. Lu, A. T. Kan, P. Zhang, J. Yu, C. Fan, and M. B. Tomson, "Phase stability and solubility of calcium sulfate in the system $\mathrm{NaCl} /$ monoethylene glycol/water," in Paper presented at the SPE International Conference on Oilfield Scale, Aberdeen, UK, May 2010.

[23] N. P. Tung, N. T. P. Phong, B. Q. K. Long, and N. H. Duy, "Scale inhibitors for co-deposited calcium sulfate and calcium carbonate in squeeze process in white tiger oilfield," in Paper presented at the SPE International Symposium on Oilfield Scale, Aberdeen, UK, May 2004.

[24] M. M. Jordan, H. Williams, S. Linares-Samaniego, and D. M. Frigo, "New insights on the impact of high temperature conditions $\left(176^{\circ} \mathrm{C}\right)$ on carbonate and sulphate scale dissolver performance," in Paper presented at the SPE International Oilfield Scale Conference and Exhibition, Aberdeen, Scotland, May 2014.

[25] J. Delorey, S. Allen, and L. McMaster, "Precipitation of calcium sulphate during carbonate acidizing: minimizing the risk," in Paper presented at the Annual Technical Meeting, Calgary, Canada, June 1996.

[26] C. D. Wehunt, H. Van Arsdale, J. L. Warner, and S. A. Ali, "Laboratory Acidization of an Eolian sandstone at 380F," in Presented at the SPE International Symposium on Oilfield Chemistry, New Orleans, LA, USA, March 1993.

[27] R. L. Thomas, H. A. Nasr-El-Din, J. D. Lynn, S. Mehta, and S. R. Zaidi, "Precipitation during the acidizing of a HT/HP illitic sandstone reservoir in eastern Saudi Arabia: a laboratory study," in Paper presented at the SPE Annual Technical Conference and Exhibition, New Orleans, LA, USA, September-October 2001.
[28] A. T. Onawole, I. A. Hussein, A. Sultan, S. Abdel-Azeim, M. Mahmoud, and M. A. Saad, "Molecular and electronic structure elucidation of $\mathrm{Fe}^{2+} / \mathrm{Fe}^{3+}$ complexed chelators used in iron sulphide scale removal in oil and gas wells," Canadian Journal of Chemical Engineering, vol. 97, no. 7, pp. 2021-2027, 2019.

[29] M. Ahmed, A. Onawole, I. Hussien, M. Saad, M. Mahmoud, and H. Nimir, "Effect of $\mathrm{pH}$ on dissolution of iron sulfide scales using THPS," in Presenced at the SPE International Conference on Oilfield Chemistry, Galveston, TX, USA, April 2019.

[30] R. Ramanathan and H. Nasr-El-Din, "Evaluation of chelating agents for iron sulfide FeS scale removal," in Paper presented at the Abu Dhabi International Petroleum Exhibition \& Conference, Abu Dhabi, November 2019.

[31] H. Gamal, S. Elkatatny, D. Al Shehri, and M. Bahgat, "A novel low-temperature non-corrosive sulfate/sulfide scale dissolver," Sustainability, vol. 12, no. 6, p. 2455, 2020.

[32] M. M. Brezinski, "New environmental options for corrosion inhibitor intensifiers," in Paper presented at the SPE/EPA Exploration and Production Environmental Conference, Austin, TX, USA, March 1999.

[33] H. Gamal, S. Elkatatny, S. Al-Afnan, and M. Bahgat, "Development of a unique organic acid solution for removing composite field scales," ACS Omega, vol. 6, no. 2, pp. 1205-1215, 2021.

[34] I. Syafii, N. Pandya, A. Sabhapondit, and H. E. Hajj, "Hightemperature acidizing: advantages of inhibitor-intensifier synergy," in Paper presented at the Abu Dhabi International Petroleum Exhibition \& Conference, Abu Dhabi, UAE, November 2016.

[35] A. I. El Menjra, A. Seyeux, D. Mercier, I. Beech, Z. Makama, and P. Marcus, "ToF-SIMS analysis of abiotic and biotic iron sulfide layers formed in aqueous conditions on iron surfaces," Applied Surface Science, vol. 484, pp. 876-883, 2019.

[36] M. Al Tolaihy, D. O. Bukhari, and A. M. Wu, "Study on the optimization of de-scaling operations in Saudi Arabian Khuff Gas wells," in Corrosion 2010, San Antonio, TX, USA, March 2010.

[37] Q. Wang, S. Shen, H. Badairy et al., "Laboratory assessment of tetrakis (hydroxymethyl) phosphonium sulfate as dissolver for scales formed in sour gas wells," International Journal of Corrosion and Scale Inhibition, vol. 4, no. 3, pp. 235-254, 2015.

[38] Q. Wang, H. Ajwad, T. Shafai, and J. D. Lynn, "Iron sulfide scale dissolvers: how effective are they?," in Paper presented at the SPE Saudi Arabia Section Technical Symposium and Exhibition, Al-Khobar, Saudi Arabia, May 2013.

[39] X. Wang, Q. Qu, S. Berry, and J. Cutler, "Iron sulfide removal: a nonacidic alternative to hydrochloric acid treatment," in Paper presented at the SPE European Formation Damage Conference \& Exhibition, Noordwijk, The Netherlands, June 2013.

[40] S. L. Berry, J. L. Boles, A. K. Singh, and I. Hashim, "Enhancing production by removing zinc sulfide scale from an offshore well: a case history," SPE Production \& Operations, vol. 27, no. 3, pp. 318-326, 2012.

[41] M. S. Van Domelen and A. R. Jennings Jr., "Alternate acid blends for HPHT applications," in Paper presented at the Offshore Europe, Aberdeen, UK, September 1995.

[42] E. Da Motta, M. Quiroga, A. Aragão, and A. Pereira, "Acidizing gas wells in the Merluza field using an acetic/formic acid mixture and foam pigs," in Paper presented at the SPE Formation Damage Control Conference, Lafayette, LA, USA, February 1998. 
[43] P. Smith, C. Clement Jr., and A. M. Rojas, "Combined scale removal and scale inhibition treatments," in Paper presented at the International Symposium on Oilfield Scale, Aberdeen, UK, January 2000.

[44] T. Almubarak, J. H. Ng, and H. Nasr-El-Din, "Oilfield scale removal by chelating agents: an aminopolycarboxylic acids review," in Paper presented at the SPE Western Regional Meeting, Bakersfield, CA, USA, April 2017.

[45] K. Sokhanvarian, H. A. Nasr-El-Din, G. Wang, and C. De Wolf, "Thermal stability of various chelates that are used in the oilfield and potential damage due to their decomposition products," in Paper presented at the SPE International Production and Operations Conference \& Exhibition, Doha, Qatar, May 2012.

[46] ASTM-D934, American Society for Testing and Materials, "Standard practices for identification of crystalline compounds in water-formed deposits by X-ray diffraction," in 1996 Annual Book of ASTM Standards, vol. 11.02, pp. 18-26, 1996.

[47] N. Aljeban, T. Chen, and S. Balharth, "Kinetics study of iron sulfide scale dissolution. Society of Petroleum Engineers," in Presenced at the Abu Dhabi International Petroleum Exhibition and Conference, Dhabi, United Arab Emirates, November 2018.

[48] B. S. Bageri, M. A. Mahmoud, R. A. Shawabkeh, S. H. AlMutairi, and A. Abdulraheem, "Filter cake porosity and permeability profile along the horizontal well and their impact on filter cake removal," in Paper was presented at the International Petroleum Technology Conference, Doha, Qatar, December 2015.

[49] C. B. Verma and M. A. Quraishi, "Schiff's bases of glutamic acid and aldehydes as green corrosion inhibitor for mild steel: weight-loss, electrochemical and surface analysis," International Journal of Innovative Research in Science, Engineering and Technology, vol. 3, pp. 14601-14613, 2014. 